of fruit hexoses. The conclusion is drawn from the ever-increasing gap between the yield of labelled carbon dioxide from $\mathrm{C}(\mathrm{I})$ and $\mathrm{C}(6)$ of glucose observed with fruit during the ripening process. Tager ${ }^{8}$, and Tager and Biale ${ }^{9}$, have reported evidence for the enrichment of glycolytic enzymes (carboxylase and aldolase) in ripening bananas, accompanied by a partial shift from the hexose monophosphate shunt to the glycolytic sequence as the climacteric rise progresses. However, a more recent communication by Young and Biale ${ }^{10}$ indicates that there is no change in the activities of triose-phosphate dehydrogenase, $\alpha$-glycerol phosphate-dehydrogenase, and glucose-6-phosphate dehydrogenase during the ripening of bananas. Either of these reports would seem to be not in line with the observation described here.

This work is supported by the U.S. Atomic Energy Commission under contract No. $A T(45-1)-573$.

$$
\text { JoHn C. Ramsex }
$$
ChiH H. Wang

Department of Chemistry and

Science Research Institute, Oregon State University, Corvallis.

${ }^{1}$ Kidd, F., and West, C., Rep. Food Invest. Board, London, 1921, 17. 2 Rowan, K. S., Pratt, H. K., and Robertson, R. N., A sstral. J. Biol. Sci., 11, 329 (1958).

Sobertion, R. N., and Turner, J. F., Austral. J. Sci. Res., Ser. B, 4, 92 (1951).

- Neal, G. E., and Hulme, A. C., J. Exp. Bot., 9, 403 (1958)

${ }^{5}$ Neal, G. E., and Hulme, A. C., J. Exp. Bot., 8, 142 (1958).

- Doyle, W. P., and Wang, C. H., Canad. J. Bot., 36, 483 (1958).

' Barbour, R. D., Buhler, D. R., and Wang, C. H., Plant Physiol., 38,396 (1958)

- Tager, J. M., S. Afr. J. Sci., 53, 167 (1956).

- Tager, J. M., and Biale, J. B., Physiologia Plantarum, 10, 69 (1957).

${ }^{10}$ Young, R. E., and Biale, J. B., Amer. Soc, Plant Physiol., Western Section, Abstracts of meeting at Davis, June 1961, 31 .

\section{Inheritance of Susceptibility to Internal Browning of Brussels Sprouts}

A DISORDER of Brussels sprouts known as 'internal browning' is causing some concern to vegetable growers. The symptoms are a necrosis of the distal ends of the leaves within the sprout, generally of those in a region centred on a line through the axis of the sprout and mid-way between its growing point and exterior surface. From a practical aspect 'internal browning' is especially troublesome because it cannot usually be detected from an external examination of the sprouts, yet quite a small number of affected sprouts may taint a large sample-especially when they are blanched for quick-freezing.

The symptoms of 'internal browning' are similar to those of a disease of cabbage which was described in the United States in 1946 as 'internal breakdown', and later in Holland as 'rand's or 'internal tipburn's. There is no evidence that the symptoms are caused by pathogens either in Brussels sprouts or in cabbage and it is probable that the disease may be classed as a physiological disorder.

Field trials of Brussels sprouts at Invergowrie ${ }^{4}$ have indicated that varieties differ consistently in their susceptibility to internal browning. To confirm whether susceptibility to internal browning is inherited, plants with high and low incidences were self-pollinated in 1958 and $28 S_{1}$ plants from each parent were examined in 1960 for the presence of this disorder. Random samples of 5 sprouts from each plant were examined internally on four different dates, and the numbers of sprouts and plants whioh showed the presence of internal browning were recorded (Table 1 ).
Table 1

\begin{tabular}{|c|c|c|c|c|c|c|}
\hline \multirow{3}{*}{$\begin{array}{l}\text { Parent plants } \\
\\
\text { Percentage of } \\
\text { sprouts with } \\
\text { internal } \\
\text { browning } \\
\text { (1958) }\end{array}$} & \multicolumn{6}{|c|}{$S_{1}$ progenies } \\
\hline & \multicolumn{5}{|c|}{$\begin{array}{c}\text { Percentage of sprouts with internal } \\
\text { browning }(1960)\end{array}$} & \multirow{3}{*}{$\begin{array}{c}\begin{array}{c}\text { Percentage of } \\
\text { plants with } \\
\text { internal } \\
\text { browning } \\
(1960)\end{array} \\
\begin{array}{c}(28 \text { plant } \\
\text { samples }) \\
\text { Total of } 4 \\
\text { harvests }\end{array}\end{array}$} \\
\hline & \multicolumn{4}{|c|}{ (140 sprout samples) } & $\begin{array}{l}(560 \text { sprout } \\
\text { samples) }\end{array}$ & \\
\hline & $\begin{array}{c}\text { Nov. } \\
7\end{array}$ & $\begin{array}{l}\text { Nov. } \\
18\end{array}$ & $\begin{array}{c}\text { Nov. } \\
25\end{array}$ & Dec. & $\begin{array}{c}\text { Total of } \\
4 \text { harvests }\end{array}$ & \\
\hline $\begin{array}{r}60 \\
50 \\
50 \\
2 \\
6 \\
0\end{array}$ & $\begin{array}{r}38 \\
29 \\
19 \\
5 \\
7 \\
2\end{array}$ & $\begin{array}{r}48 \\
26 \\
13 \\
6 \\
1 \\
0\end{array}$ & $\begin{array}{r}45 \\
21 \\
8 \\
6 \\
6 \\
1\end{array}$ & $\begin{array}{r}29 \\
14 \\
15 \\
7 \\
8 \\
4\end{array}$ & $\begin{array}{r}40 \\
23 \\
14 \\
6 \\
6 \\
2\end{array}$ & $\begin{array}{l}98 \\
96 \\
89 \\
46 \\
61 \\
25\end{array}$ \\
\hline
\end{tabular}

Internal browning was fairly prevalent at Invergowrie in the autumn and winter of 1960 and some plants in each of the progenies were affected, even in those progenies from the parent plant which produced no internally browned sprouts in 1958. However, a close relationship between the occurrence of internal browning in the parent plants and their progenies can be detected. This clearly indicates that proneness to internal browning is inherited, and further studies on the mode of inheritance are being made at Mylnefield. Similar results on the inheritance of a tendency to internal tipburn in cabbage have recently been reported by Poerink ${ }^{5}$. These findings suggest that practical difficulties with internal browning might be overcome by breeding resistant strains.

W. Greta Priestrey C. NoRTH

Scottish Horticultural Research Institute,

Mylnefield, Invergowrie, By Dundee.

${ }^{1}$ Shafer, J., and Sayre, C. B., Proc. Amer. Soc. Hort. Sci., 47, 340 (1946).

? Jensma, J. R., Zaadbelangen, 8, 196 (1954).

${ }^{3}$ Nieuwhof, M., Euphytica, O, 203 (1960).

- North, C., Frith, L. H., and Taylor, H., Hort. Res., 1, 37 (1961).

${ }^{5}$ Poerink, H. J., Meded. Proefst. Volle Grond., 19 (1961).

\section{Separation of Anthocyanins by Cellulose Column Chromatography}

PAPER chromatography has greatly facilitated the separation, isolation and identification of anthocyanins and other water-soluble plant pigments ${ }^{1}$. Large-scale separations have been accomplished by means of adsorption chromatography on cellulose ${ }^{2,3}$ or magnesol ${ }^{4}$ columns. Attempts to obtain distinct bands of anthocyanins using cellulose column chromatography according to Endo's ${ }^{3}$ procedure were unsuccessful. A method used by Chorney ${ }^{5}$ to separate sugars quantitatively by means of cellulose column chromatography has proved to be eminently satisfactory for large-scale separation of a mixture of anthocyanins.

The column $(3.0 \mathrm{~cm}$. diam. and $65.0 \mathrm{~cm}$. length) was packed with dry cellulose powder (Whatman standard grade) and washed thoroughly first with water and then with the upper phase of the solvent mixture of butanol : glacial acetic acid : water $(5: 1: 4, v / v)$ used both to develop and to elute the anthocyanins. The column was irrigated with methanol and dried by drawing air through it. $10 \mathrm{gm}$. of cellulose powder was then removed from the column. $5 \mathrm{ml}$. of a methanol-hydrochloric acid extract of anthocyanins from flowers of Collinsia heterophylla Buist ${ }^{6}$ was adsorbed on about $5 \mathrm{gm}$. of the dried washed cellulose powder and dried with a jet of warm air, added to the column, and packed to give a thin uniform layer. The remainder, approx- 